\title{
Issures
}

\section{Paradigm Lost? The Fate of Literature in the Age of Theory}

\author{
Geratdo L. DE Solsa
}

$\mathrm{W}$

HAT ROLIOWS HERF ARE THE PAPLRS from the special plenary session "Paradigm Lost?" at the annual meeting of the Shakespeare Association of America, in Washington, D.C., on 28 March 1997. The session was convened to consider the impact of theory on the teaching of Shakespeare and the extent to which the collective theoretical debates within the profession are redefining our role and responsibilities as educators and refashioning our identity as teachers of Shakespeare. In my role as convener, I hoped to steer the discussion away from the tug-of-war between the political Right and Left so that we could understand the changes brought about by the pursuit of theory and come to a consensus about the impact of these changes on the liberal-arts curriculum and the training that our students and future teachers are receiving in our undergraduate and graduate classrooms.

The idea for the session came to me at a meeting of my university's English department, where discussion veered from a specific English course to broad curriculum matters and thence to the place of Shakespeare in the university's undergraduate core curriculum. At Xavier, a Jesuit university, we have a rigorous core curriculum in such areas as philosophy, theology, English, and the sciences. This curriculum grows out of a philosophy of general education that stresses the development of critical and creative thinking and (to quote the Xavier Lniversity Core Curriculum Papers) explores "multiple avenues to truth that reflect the complexity of the human spirit" and that lead, finally, to "responsible moral action." 'The lthics/Religion and Society focus endeavors "to make students sensitive to the ethical issues that can be raised in many disciplines" and seeks to offer an integrated study of ethical issues in a Jesuit context. Within this focus a course entitled "I iterature and the Moral Imagination" studies "the representation of moral conflict and moral decision in a variety of important literary texts," emphasizing the analysis of, response to, and interpretation of such texts.

In pracice, however, "I itcrature and the Moral Imagination" addresses widely divergent topics and themes and takes different shapes in a sort of free-for-all approach. The course sometimes includes texis that are not "literature," let alone "important literary texts." Some faculty argued that the course should, at least in part, deal with great books. A Victorian scholar offered what seemed to me a rather modest proposal. He suggested that the overall selection of texts for the course should remain open, except for one Shakespeare play, any play.' He apparently assumed, first, that no one would question Shakespeare's unassailable canonical position in English literature, and, second, that all undergraduate students should study at least one play by Shakespeare. To the amazement of many, a few members of the department argued from various intellectual, theoretical, and personal positions against the inclusion of a Shakespeare play in a course on literature and the moral imagination; nor did these members appear disturbed by the fact that the vast majority of undergraduate students at Xavier Lniversity can graduate without ever encountering a Shakespeare play. For the first time in my career. I entertained the thought that perhaps Ben Jonson was wrong when he wrote that Shakespeare "was not of an age, but for all time!"

${ }^{1}$ This would follow the model of the philosoply course in the Fothes Religion and society focus, in which all sections rearl Plato's Republic 
The rift within the English department mirrors a rift, on the one hand, between Fnglish departments and the rest of the university and, on the other, between academia and the culture at large. Our students seem to want more of the classics, not less. Our scientists, theologians, philosophers, and economists expect our graduates to be well rearl in such writers as Shakespeare, Dante, Milon, Austen, and Dickinson. The press castigates Fnglish departments for a neglect of the classics. Sensational newspaper headlines stare us in the face: "Vulgarity Run Amok in the Halls of Ivy: Fnglish Departments Have Marginalized the Greats in Favor of the Trendv." "2 Others blame multiculturalism for the woes of our higher-education system. ${ }^{3}$ Theorist Frank Lentricchia forsakes theory and announces to the world a contradiction between his public self (the disgruntled "Dirty Harry of literary theory" ") and his private self (the lovable, loving reader and teacher of literature)."

Two questions naturally come to mind: Could our theoretical debates be somehow responsible for this state of affairs? Is theory displacing literature in the classroom? Obriously, much of the criticism leveled at English departments reflects a backlash against what is perceived as the prevailing liberal political agenda of academic circles. Fet the criticism comes at a time when literary theory itself may be undergoing a profound transformation. I cannot remember the last time I heard the word logorentrism at an annual meeting of the Shakespeare Association. The alanas-alreadys of deconstruction date one's prose as surely as do the crudest forms of Freudianism or of the social history inspired by Lawrence Stone. We are clearly in a moment of transition. If the period from the carly 1980 s to mid-90s was the heyday of theory, we are now seeing what once scemed unshakable theories lose their vitality. Rather than expressions of textual, cultural, or philosophical verities, literary theory is increasingly being viewed as mere speculation. Within U.S. and British academic circles, however, theory has proven to be a cat with nine lives, merging and shifting to produce diverse theoretical chusters, such as cultural studies, new historicism, and various brands of gender criticism.

"Pararligm Lost?" did not seek to examine the role of theory in our lives or to analyze theory as an agent of social reformation or to question the legitimacy of theory as an intellectual pursuit. Although we tried not to frame the debate in terms of the primacy of literature over theory or vice versa, this issue inevitably cmerged. As teachers of Shakespeare, we were primarily concemed with the classroom and practical pedagogial questions: First, is there a place for theory in the undergraduate Shakespeare survey? Sccond, is theory indeed displacing literature in the literatue classroom?

The issue of "displacement" often comes up in the discussion of the fate of literature in the age of theory. The argument can be summarized as follows: Theory has precipitated a crisis of identity for English departments. English as a discipline has lost its sense of mission and purpose. Through deconstruction, new historicism, cultural studies, and gender sudies, we have seen the wholesale importation of methodologies and interests of such disciplines as history, anthropology, and philosophy. These other disciplines shape and determine the questions and issues raised in the literature classroom. Litrature may thus become an interest secondary to these other disciplines. Having assumed a predominantly anthropological and historical focus, literary studies and scholarship are neglecting or abandoning the literary imagination as their unique and legitimate object of enquiry. Works of the human inagination are becoming footnotes in larger historical, cultural pursuits.

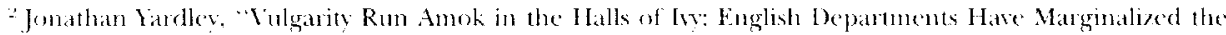

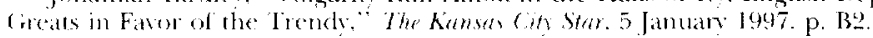

See, for example, Willian H. Honan, "Girriculum and Culure: New Round ls Opened In a seholarly Fistfight," The Wea Fonk Times, 21 Kugust logti, p. Alt.

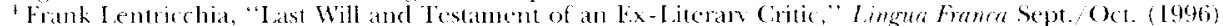
$59-67.45$. 59-60. He writes: "In private, I was tranquility personified, in public, an actor in the endless strife

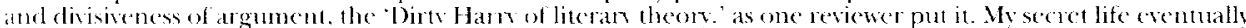
was to be shaned with students in my undergraduate chassoom. while my public life as literay intellectual rentinted to be plased out in the graduate dascrom. Two tepes of classom: two selves unhappy with one another" $(59-100)$
} 
The essays from the "Paradigm I.ost?" session explore in different ways the fate of literature in the age of theory, raising divergent theoretical, practical, and pedagogical questions. The presentations range from theory as a pedagogical technique or tool to be deployed or avoided in the literature classroom to the inseparability of literature and theory to the inevitability of theory. None of the speakers, however, questions the validity of theory as a legitimate area of academic pursuit, and some offer moving testimonials about how theory challenges them and their students and revitalizes their classrooms.

Obviously, Shakespeare does not face any immediate danger of being displaced by theory. Notwithstanding the disagreement in my own department, I think that an overwhelming consensus prevails in the profession and in the culture that Shakespeare has a place in the curriculum and an importance as both a literary genius and a cultural phenomenon. Yet in our postmodern taste for ideological confrontation and the oppositional, we as Shakespeareans may in fact be forgetting the art of diplomacy and the virtues of compromise. We may be allowing ourselves to be redefined and refashioned by our theoretical debates, and in the process, we may be recreating the world in our own image.

We may have only begun to assess the overall impact of our theoretical pursuits on university curricula, on the everyday life of our English departments, and on the image that we project of ourselves. But theory or no theory, we have failed if we teach our students to hate what we love or if we are unable to educate our administrators, legislators, and our culture at large about the importance and excitement of what we do.

In her 1980 inaugural address as president of the Modern Ianguage Association, Helen Vendler insoked Wordsworth's sow at the end of The Prelude: "What we have loved, Others will love, and we will teach them how." She added: "If we succeed at all in teaching others, from freshmen to graduate students, to love what we have loved, we hope that some of them will become the teachers who will replace us - and that thes will teach out of love. and write out of love, when they do write." I would go farther: our primary challenge is to encourage a love for Shakespeare and the arts not only in potential teachers but also in a future generation of scientists, legislators, attornevs, and accountants. If theory helps us to achieve this cond, so much the better. If it does not, we must reassess the place of theory in the classroom.

\title{
Teaching the Resonances
}

\author{
Bruce R. SMITH
}

$\mathrm{H}$

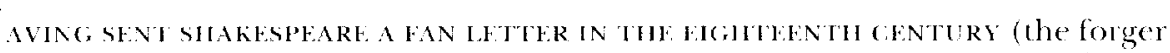
William Henr Ireland acted as amanuensis), Queen Elizabeth I was only too happy to come to his aid in April 1996. The occasion was not a roxal progress but at teach-in at Georgetown University. She had been invited by the organizers of the event, the National Alumni Forum. When informed-incorrectly-that Shakespeare was being dropped from the English Department's program of studies, the queen replied, "Excise Shakespeare from the curriculum? Stulf and nonsense." Turning to the students, she cried, "Stand up for Master Shakespeare!"' The queen was in good company. Saul Bellow hat sent a leter of support. William Peter Blatty, author of the Lxorrist, had issued an impassioned statement. Since Georgetown was dropping Shakespeare from its curriculum, Blatty was dropping Georgetown from his will:

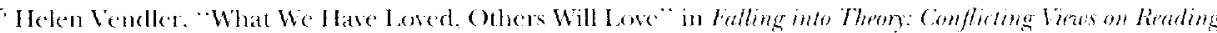

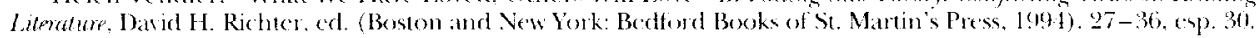

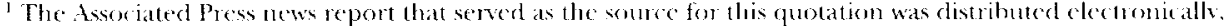
without tite or attribution, on 30 Aptil 1996. Sor also catrol Innerst. "Teach-in' goes all out in hailing

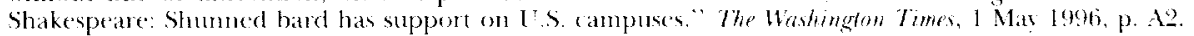

